\title{
Noticias sobre la judería y sinagoga de Béjar (Salamanca)
}

Marciano DE HERvÁs *

De la historia de los judíos de la villa de Béjar han publicado noticias parciales A. Martín Lázaro ${ }^{1}$, G. Rodríguez López y V. Agero Teixidor ${ }^{2}$. H. Graezt, Y. Baer e I. Loeb ${ }^{3}$ dedican un capítulo al malsín bejarano y al pietista rabí Hayyim ibn Yehudá ibn Musa. De la sinagoga se ha ocupado F. Cantera Burgos ${ }^{4}$, cuyo criterio comparten J. L. Lacave ${ }^{5}$ y J. García Atienza ${ }^{6}$. Algunos datos específicos de la

*mdehervas@navegalia.com.

1 A. MARTín LÁZARO, «Colección diplomática de la iglesia del Salvador de la ciudad de Béjar», Revista de Ciencias Jurídicas y Sociales [=RCJS] 4 (1921) págs. 84-149; ID., «Colección diplomática municipal de la ciudad de Béjar», RCJS 4 (1921) págs. 287-304 y 449-464; ID., «Documentos para la Historia de Béjar», RCJS 6 (1923) docs. 19-23, págs. 193-208.

${ }^{2}$ G. Rodríguez López y V. Agero TeIXIDor, Contribución al estudio de la Historia de Béjar (Béjar 1919).

${ }^{3}$ Y. BAER, Historia de los judios en la España cristiana. De la catástrofe de 1391 a la Expulsión, 2 (Madrid 1981) págs. 510, 516, 660 y 714; manejamos la edición de H. GRAETZ, Histoire des juifs. De l'époque du gaón Saadia (920) à l'époque de la reforme (1500), 4 (París 1893) págs. 349-350; I. LOEB, «Polémistes chrétiens et juifs en France et en Espàgne», Revue des Ètudes Juives 18 (1889) págs. 219-242: págs. 230-231; Enciclopedia Judaica castellana, 8 (México 1950) pág. 563.

${ }^{4}$ F. Cantera Burgos, Sinagogas españolas (Madrid 1955; reimpr. 1984) págs. 174-175, incluye fotografía de la supuesta sinagoga.

5 J. L. LACAVE, Juderías y sinagogas españolas (Madrid 1992) pág. 267, que omite en Guía de la España Judia. Itinerarios de Sefarad (Madrid 2000) pág. 65.

6 J. García Atienza, Guía judía de España (Madrid 1978), y Caminos de Sefarad (Barcelona 1994).

Sefarad 63 (2003) págs. 331-370

(C) CSIC

ISSN 037-0894 
judería los hallamos en J. C. Aguilar y M. ${ }^{a}$ C. Martín Martín ${ }^{7}$. C. García Martínez ${ }^{8}$ y J. L. Majada Neila ${ }^{9}$ ofrecen noticias generales sobre los judíos bejaranos. Es fundamental para conocer la historia de los judíos el texto del fuero actualizado por J. Gutiérrez Cuadrado ${ }^{10}$, la documentada regesta del profesor C. Carrete Parrondo ${ }^{11}$, cuyos textos utilizan M. ${ }^{a}$ Fuencisla García Casar ${ }^{12}$ y A. Avilés Amat ${ }^{13}$, los documentos medievales de A. Barrios García y A. Martín Expósito ${ }^{14}$ y por último la serie documental «Judería errante» de J. Muñoz Domínguez, con sus aportaciones de trabajo de campo ${ }^{15}$. Los datos fiscales de los judíos del señorío bejarano han sido publicados por A. Martín Lázaro, L. Suárez Fernández, J. Martínez Moro y M. de Hervás ${ }^{16}$.

\section{SITUACIÓN JURÍDICA DE LOS JUDÍOS EN EL FUERO DE BÉJAR}

La reconquista cristiana de la Alta Extremadura por Alfonso VIII de Castilla a finales del siglo XII marca el origen del asentamiento de las comunidades judías en el obispado de Plasencia, a cuyo feudo

7 J. C. Aguilar y M. ${ }^{a}$ C. Martín Martín, Aproximación a la Historia medieval de Béjar (Salamanca 1989).

${ }^{8}$ C. GARCÍA MARTÍNEZ, Béjar en su historia, 1-3 (Salamanca 1989-1993).

9 J. L. MAJAda Neila, Historia de Béjar (1209-1868) (Salamanca 1998).

10 A. Martín LÁZARo, Fuero castellano de Béjar (siglo XIII) (Madrid 1925), y J. Gutiérrez CuAdrado, Fuero de Béjar (Salamanca 1976).

${ }^{11}$ C. CARrete Parrondo, Fontes Iudaeorum Regni Castellae: I. Provincia de Salamanca (Salamanca 1981) págs. 41-54.

12 M. " F. GARcía CASAR, El pasado judio de Salamanca (Salamanca 1987) págs. 26, 60, 66, 90, 124, 134-136, 156-157, 161 y 171.

13 A. Avilés Amat, Judios de Béjar: Consideraciones sobre su vida e historia (Béjar 1994).

14 A. BARrios García y A. MARTín Expósito, Documentación medieval de los archivos municipales de Béjar y Candelario (Salamanca 1986).

${ }^{15} \mathrm{Ha}$ sido editada en 26 capítulos en el periódico Béjar Información 5 (16 junio-15 diciembre 2001).

16 A. Martín LÁzaro, «Documentos Béjar», doc. 11, págs. 107-109; L. SUÁREZ FERNÁNDEZ, Documentos acerca de la expulsión de los judios (Valladolid 1964) págs. 65-81; J. MARTínez Moro, La renta feudal en la Castilla del siglo XV: Los Stúñiga, consideraciones metodológicas y otras (Valladolid 1977) págs. 53, 71, 93 y 96; y M. DE Hervas, Documentos para la Historia de los judios de Coria y Granadilla (Coria 1999) docs. 34-52. 
pertenece la villa y tierra de Béjar ${ }^{17}$. Es de suponer que la repoblación judía del concejo urbano de Béjar se hiciese con familias procedentes de las juderías del obispado de Ávila en las primeras décadas del siglo XIII.

A finales del siglo XIII o principios del XIV, la comunidad judía de Béjar dispone de una amplia legislación jurídica vertebrada en cuarenta y cinco rúbricas, que establece los límites de sus relaciones sociales y comerciales con cristianos y musulmanes ${ }^{18}$. Las necesidades de los monarcas por repoblar los concejos castellanos, escasamente desarrollados, con las minorías religiosas imprimen un signo de tolerancia a las normativas regias en las primeras décadas de la Reconquista. Así, el fuero de Béjar garantiza la igualdad de condiciones a los judíos pobladores de la villa (rúb. 14), y plena libertad para acudir a la feria anual que se celebra durante la fiesta de Pentecostés (rúb. 32).

Como medida de prevención, el código foral bejarano regula el funcionamiento del baño público a judíos y cristianos. Los cristianos tienen reservado el baño los martes, jueves y sábados, los judíos acuden el viernes y el domingo y las mujeres -no especifica su condición religiosa- el lunes y el miércoles (rúbs. 67 y 69). Algunos historiadores han advertido en esta medida cierta tensión social entre judíos y cristianos.

También la comunidad judía de Béjar goza de autonomía penal para juzgar los pleitos entre judíos. En cambio, los juicios mixtos se celebran en un tribunal de arbitraje formado por un juez judío y otro cristiano (rúb. 853), pudiendo presentar el litigante uno o varios testigos judíos y cristianos (rúb. 855). Las sesiones del tribunal se celebran delante de la puerta de la alcazaba (rúb. 871), en ocasiones, en el corral de los alcaldes (rúb. 887). Los judíos bejaranos pueden recurrir a un tribunal superior de arbitraje constituido por varios

\footnotetext{
17 En 1187, Alfonso viII concede al obispo de Ávila la tercera parte de las rentas reales de Plasencia, incluido el bedinazgo de los judíos (en Archivo Histórico Nacional [=AHN], Clero, carp. 18, núm. 19, microfilm rollo 1881).

${ }^{18}$ Utilizamos el texto de J. Gutiérrez CuAdrado, Fuero de Béjar, recogido por C. Carrete Parrondo, Fontes, doc. 77.
} 
magistrados judíos y cristianos (rúb. 854). También posee la comunidad judía su propia cárcel custodiada por el bedín, una especie de alguacil y policía de la aljama en la acepción contemporánea (rúbs. 858 y 860). El código legislativo respeta la libertad de culto permitiendo a los judíos formular el juramento sobre la Torá en cuantías superiores a cuatro mencales o seis sueldos (rúb. 880), y respeta las festividades cúlticas cristiana y judía en cuyos días no pueden celebrarse pleitos (rúb. 882).

Tiende a reflexionarse que el mestizaje cultural es la fuente de los conflictos judeocristianos. Sin embargo, las convulsiones religiosas emanan de una legislación arbitraria en determinadas materias, que no equipara en el mismo plano de igualdad a judíos, musulmanes y cristianos. Así, la segregación alcanza por igual a ambos colectivos en el ámbito de las relaciones sexuales, al prohibir el fuero la promiscuidad entre judío y cristiana, o viceversa: «muger que prendieren con moro o con iudío quémenlos a amos» (rúb. 350). En la prohibición de las relaciones sexuales entre miembros de distintas confesiones religiosas se expresa, según Baer ${ }^{19}$, el origen de las «manifestaciones de tensión religiosa y racial». Sin embargo, cabe argüir que el judaísmo tampoco contempla con buenos ojos el matrimonio entre judíos/as y cristianas/os. Por consiguiente, esta supuesta segregación más bien debemos considerarla como una medida de prevención, para evitar tensiones en la sociedad multicultural bejarana, como sucede con la regulación del uso del baño público.

Los delitos con derramamiento de sangre y muerte de un judío o cristiano bejarano en los baños públicos en los días no autorizados por el fuero quedan impunes ante la ley (rúb. 69). El cristiano que cause heridas o quite la vida a un judío paga cien sueldos al rey; en caso de herida es necesario el testimonio favorable de dos de los cuatro testigos designados por el municipio, o de doce vecinos en caso de muerte (rúb. 890). En cambio, si el judío causa heridas o mata al cristiano abona la caloña según el fuero, necesitando el testimonio favorable de dos de los cuatros testigos judíos si hay herida, o de doce judíos en caso de fallecimiento (rúb. 891). Sin embargo,

19 Y. BAER, Historia de los judios, 1, pág. 72. 
las diferencias forales se manifiestan en la percepción de la caloña o indemnización económica que perciben los judíos y cristianos bejaranos. La caloña de los judíos pertenece exclusivamente al monarca, «ca los iudíos siervos son del rey e acomendados pora la bolsa del rey propria (rúb. 892)».

En la consideración jurídica de la época se proyecta el nivel de inferioridad al que está sometida la minoría judía de Béjar frente al morador y vecino cristiano, empero en una escala ligeramente superior a la del vecino musulmán.

El código foral también regula las condiciones del préstamo judío, el sistema de contratación y la percepción de los intereses usurarios, recortando los abusos de los prestamistas cuyas cartas de obligación deben efectuar ante testigos cristianos y judíos (rúbs. 855 y 876).

El judío bejarano no puede vender la prenda empeñada por el cristiano en la tienda o en la Alcaicería. Pero puede deshacerse del objeto si está autorizado por el propietario y tiene el testimonio favorable de un judío y un cristiano; en caso contrario, debe doblar el coste originario de la prenda (rúb. 877). Si la deuda ha sido doblada y no le ha sido satisfecho el importe, el prestamista judío puede entregar la prenda al corredor para su venta (rúb. 878). El propietario de la prenda puede recuperarla y venderla a través del corredor, a cambio de satisfacer la totalidad del importe del préstamo (rúb. 879).

El «corredor» es un oficial municipal o vendedor público ambulante autorizado por el concejo de la villa y aldeas para facilitar la venta de ciertos productos en los pueblos de la comarca. El «corredor» está autorizado a vender armas intramuros de la villa. Su designación, que corre a cargo del juez o alcalde, puede recaer en un «cristiano o iudío o moro» (rúb. 533). Su salario está regulado por el código foral. Recibe un dinero por cada maravedí que cobra de las ventas (rúb. 566). El hurto está penalizado con el corte de orejas o la ceguera, según sea la cuantía sustraída (rúb. 565). En las ordenanzas municipales de Béjar de 1452, la figura del «corredor» representa un papel fundamental en el desarrollo del comercio interior bejarano. Es muy posible que este oficio fuese desempeñado por algunos judíos de Hervás en la segunda mitad del siglo XV, 
porque cuando éstos se convierten forzadamente al cristianismo en 1492, asumen un protagonismo relevante en la especialización de la venta ambulante de paños y tejidos por las plazas y mercados de las ciudades y villas del reino de Castilla.

No obstante, el judío bejarano tiene vedado el acceso a otros cargos públicos, como los oficios de portaguero y merino, que tampoco pueden desarrollar ninguno de los vecinos de Béjar (rúb. 22).

¿Hay conversos en la villa de Béjar en el siglo XIII? Dos artículos del código foral nos permiten detectar la existencia de cierta población conversa: «del qui tornar su moro christiano» (rúb. 222) y «de vuestros mançebos e tornadizos» (rúb. 223). Pero la normativa foral se refiere específicamente a los esclavos musulmanes que han sido convertidos al cristianismo por sus propietarios, o bien por ellos mismos para liberarse del yugo de la esclavitud cristiana.

En definitiva, las ordenanzas forales de la villa de Béjar respetan la autonomía institucional de la aljama judía garantizando plenamente su independencia jurídica, la práctica cultual mosaica y la casi igualdad ante la ley en los conflictos económicos, con un atisbo discriminatorio en algunas de sus leyes frente al cristiano.

\section{LA LEY DE USURA, 1260}

En 1248 Fernando III resuelve una contienda sobre el tema de los pastos y montazgos entre los concejos urbanos de Béjar y Plasencia, disponiendo «que los de Plazencia que anden e pascan en los términos de Béiar a fuero de Béiar» ${ }^{20}$.

$\mathrm{Al}$ hilo de esta noticia resulta que la villa de Béjar disfruta de la carta foral otorgada por el monarca Alfonso VIII a comienzos del siglo XIII, inspirada en la de Cuenca, en la que muy posiblemente incluya una legislación específica para la comunidad judeobejarana.

20 Archivo Municipal de Béjar [=AMB], I.E. 4.15; recogido por A. MARTín LÁZARO, «Colección municipal», doc. 1, págs. 290-291. 
Hacia 1260, según J. Gutiérrez ${ }^{21}$, compone el fuero de Béjar un conjunto de normas, costumbres y privilegios que se desarrollan a partir del privilegio de repoblación concedido por Alfonso VIII, pero no tiene un códice fijado por escrito hasta fines del siglo XIII o principios del XIV.

En cualquier caso, el primer documento que menciona la existencia de una comunidad judía en la villa de Béjar es una carta otorgada por el soberano Alfonso X, en abril de 1260, en la que fija las condiciones del préstamo a interés entre judíos, musulmanes y cristianos ${ }^{22}$. A tenor de la ley alfonsina, en la década de los años sesenta del siglo XIII reside una comunidad judía en la villa de Béjar.

En términos jurídicos de la época, la usura es un préstamo monetario que ejerce una persona, con prenda o sin ella, a un elevado interés. Por estas fechas entra en vigor la legislación eclesiástica que prohíbe ejercer el préstamo a interés a los cristianos. También las leyes talmúdicas tienen prohibido a los judíos entregar dinero a interés a otro judío, pero pueden efectuar transacciones comerciales y empréstitos a miembros de otras creencias religiosas. Es en este tiempo cuando los judíos se especializan en la profesión de prestamista.

\section{LOS JUDÍOS EN EL REINADO DE ALFONSO X}

En el reinado de Alfonso X (1252-1284), los procuradores del reino plantean en las cortes de Castilla y León el tema de la usura judía. Presionado por las quejas de los procuradores de los concejos urbanos que denuncian el incremento del precio del dinero, el soberano declara ilícito el interés prestatario superior al 33,3\%. Los deudores pueden prorrogar el empréstito durante un plazo máximo de tres años, fijando el techo de la renovación del crédito hasta que el interés iguale al precio del dinero.

Los recelos levantados por la elevada cuantía del crédito usurario en la villa de Béjar fuerzan a la corona a la imposición de medidas

21 J. Gutiérrez CuAdrado, Fuero de Béjar, pág. 25.

22 AMB, I.E. 2.8. 
especiales. En el señorío de Béjar, feudo de la reina Violante de Aragón, la corona aplica la ley de usura el 22 de abril de 1260. Alfonso $\mathrm{X}$ regula las condiciones prestatarias legales por las cuales deben regirse judíos, cristianos y musulmanes en Béjar. En primer lugar, el monarca dispone que la solicitud de un préstamo, la renovación de una deuda, o la pignoración de una prenda tiene que efectuarse en presencia de dos alcaldes, uno cristiano y otro judío o musulmán, según los casos, el escribano del concejo y varios testigos judíos y cristianos. El deudor debe abonar el capital y los intereses al alcalde o escribano para que éste los transfiera al acreedor. Por otro lado, el prestamista debe demostrar que las prendas empeñadas no son producto de un robo. En este caso, el dueño puede recobrar la pieza empeñada si demuestra que es de su propiedad.

Amortizada la deuda, el escribano rompe el contrato firmado, pero si queda pendiente una parte debe redactar una nueva carta de obligación, descontando los intereses devengados. Finalizado el plazo de la usura, si el acreedor se niega a cobrar los réditos, el deudor puede entregar al alcalde el contrato y la cuantía económica. Las cartas de obligación redactadas con anterioridad a 1260 expiran a los doce años y las emitidas con fecha posterior al cabo de ocho. El incumplimiento de las ordenanzas faculta a los merinos, alcaldes y recaudadores de la corona para proceder a la incautación de los bienes en litigio.

Por consiguiente, en 1260, encontramos en la aljama de la villa de Béjar un colectivo de prestamistas judíos y musulmanes autorizados por la corona para ejercer el préstamo de dinero en un marco jurídico adecuado con un tipo de interés específico y con las normas de la hipoteca. En la Alcaicería, los judeobejaranos instalan sus tiendas para comerciar los paños de Castilla y las telas de seda, a la vez que ejercen la actividad del préstamo a interés, reglamentada por la ley foral bejarana. Así pues, la Alcaicería es un espacio urbano reservado para el desarrollo de las actividades comerciales de la villa.

En puridad, la normativa de la usura judía está dirigida al concejo de la villa y aldeas de Béjar, pero no debe entenderse que en este tiempo residen judíos en los pueblos del señorío. No hemos podido 
constatar documentalmente la presencia de judíos en las aldeas de Béjar hasta el comienzo del siglo XV. En los días de la reina Violante de Aragón, en 1277, la población pechera del señorío de Béjar atraviesa dificultades demográficas acuciada por el incremento de caballeros y ballesteros. Así las cosas, los vecinos de la villa «eran pocos e muy pobres por razón que los omnes se eran idos de la tierra a morar a otros logares, e porque los cavalleros e los ballesteros se acrecentavan por las franquezas que el rey les faze» ${ }^{23}$.

Con el ánimo de homologar los distintos modelos forales de los municipios castellano-leonés, en 1261 Alfonso X impone el fuero regio al señorío de Béjar sustituyendo el estatuto foral otorgado por su bisabuelo Alfonso VIII, que restituye en octubre de $1272^{24}$.

La corona de Castilla considera a los judíos sus súbditos y únicos vasallos, imponiendo en contrapartida un sistema fiscal comunal e individual que deben satisfacer, a cambio de su protección real. Durante el gobierno de Sancho IV se realiza un padrón fiscal de las aljamas judías de Castilla, conocido como el repartimiento de Huete, elaborado entre los años de 1290 y $1291^{25}$. Aunque este censo no puede considerarse una relación nominal exhaustiva de todas las juderías hispanas, recoge el dato de las cuatro únicas comunidades judías que existen en el obispado de Plasencia en 1290: Plasencia satisface a la corona $16.244 \mathrm{mrs}$, Trujillo $3.730 \mathrm{mrs}$, Béjar 3.430 mrs y Medellín $3.348 \mathrm{mrs}$. Es de suponer que la comunidad judía de Plasencia es la más poblada de la diócesis placentina, a juzgar por la cuantía fiscal aportada, mientras que el índice demográfico de las comunidades judías de Béjar, Medellín y Trujillo se encuentra mucho más equilibrado.

Muy próxima a la aljama de Béjar, en la demarcación del obispado de Ávila, se desarrollan las juderías de El Barco de Ávila,

23 AMB, I.E. 1.3; A. Martín LÁZARO, «Colección municipal», doc. 6, págs. 302-303.

24 AMB, I.E. 2.8 Y 1.1; A. MARTín LÁZARO, «Colección municipal», doc. 4, págs. 295-302.

${ }_{25}$ AHN, Clero, leg. 7218, núm. 4, fol. 1v; recogido por C. CArrete PARRONDO, «El repartimiento de Huete de 1290», Sefarad 36 (1976) págs. 121140: pág. 128. 
Bonilla de la Sierra y Piedrahita, que tributan una suma de dinero superior a la de Plasencia ${ }^{26}$. No olvidemos que en los siglos XIII y XIV las comunidades judías de la diócesis de Ávila, en cuyo distrito diocesano y administrativo nacen los concejos urbanos de Plasencia y Béjar, están mucho más pobladas que las del obispado de Plasencia, en fase de formación. Esto nos induce a pensar en una posible repoblación de las comunidades judías de la diócesis de Plasencia, o al menos de las comunidades de Béjar y Plasencia, con colonos judíos procedentes de las juderías vecinas del obispado de Ávila.

\section{LA CUESTIÓN JUDÍA EN LOS REINOS DE FERNANDO IV Y ALFONSO XI}

En los primeros años del reinado de Fernando IV (1295-1312), los municipios de Castilla presionan a la corona en el escenario de las cortes de Valladolid, reclamando en 1298 la entrega de los oficios del arrendamiento y recaudación de los impuestos fiscales a los hombres buenos de las villas de cada lugar, y no a otras personas ${ }^{27}$. Esta medida legislativa repercute en la vida de la aljama de Béjar. Así, el 24 de febrero de 1298 Fernando IV confirma a la villa de Béjar los privilegios forales de sus antecesores, disponiendo que los judíos en materia de usura se atengan al fuero regio ${ }^{28}$.

Los intentos de los concejos urbanos de Castilla por desplazar a los judíos de los órganos financieros del Estado debemos englobarlos dentro del marco de las aspiraciones políticas municipales por conseguir una mayor independencia frente al gobierno central, procurándose el control de los mecanismos financieros y jurídicos. Pero de ningún modo debemos considerarlos como medidas discriminatorias específicamente antijudías. De hecho, los cuadernos de las cortes de Castilla y León reflejan la oposición de los concejos urbanos a la participación de oficiales ricos hombres, caballeros, clérigos, musulmanes y judíos en el ejercicio del préstamo a interés.

26 C. Carrete Parrondo, «El repartimiento de Huete», pág. 128.

27 Cortes de los antiguos reinos de León y Castilla, I (Madrid 1861) art. 13, pág. 142 .

28 AMB, I.E. 2.10. 
En las cortes de Medina del Campo de 1305, Fernando IV veta el acceso a los judíos, ricos hombres y caballeros en el sistema fiscal de la corona, dejando el camino expedito a los sesmeros, vecinos y moradores de las villas ${ }^{29}$. Sin embargo, en las cortes de 1325 Alfonso XI permite que los caballeros y hombres buenos abonados moradores en las ciudades y villas intervengan en el organismo fiscalizador ${ }^{30}$.

En los últimos días del reinado de Fernando IV, entre los años de 1310 y 1312, la aljama de Béjar aplica los rigores de la ley contra un malsín, un judío difamador, imputado en el levantamiento de calumnias a sus correligionarios de Béjar. Del judío chivato bejarano nos informa el juez rabí Yom Tov ben Abraham Asbilí en una de sus responsas. Parece ser que el tribunal rabínico condena al calumniador a la amputación de la lengua y de una mano por un delito que no revela la documentación. El inculpado recurre al monarca argumentando ciertas irregularidades jurídicas, como que los jueces bejaranos no le han permitido apelar al tribunal de la corona, y que han recusado el testimonio de testigos considerados inhábiles.

Así las cosas, rabí Yom Tov Asbilí replica en la corte real que los razonamientos del malsín bejarano carecen de fundamento jurídico, por cuanto que el juez judío no está obligado a tener en cuenta sus peticiones, particularmente en los casos especiales donde se pretende vigilar la reforma del nuevo orden social judío y salvaguardar las leyes de la Torá. Finalmente, al delator le aplican la mutilación ${ }^{31}$.

\section{SUPRESIÓN DE LAS ESCRIBANÍAS JUDÍAS, 1330}

La cuestión judía aflora a la superficie en la villa de Béjar durante la minoría de edad del soberano Alfonso XI (1312-1350), amalgamada con las reclamaciones de los municipios de Castilla que reivin-

29 Cortes, I, arts. 9 y 10, pág. 175.

30 AMB, I.E. 2.11.

Sobre el malsín bejarano véase Y. BAER, Historia de los judios, 2, págs. 660-661 y 714, citado por C. Carrete Parrondo, Fontes, doc. 78. 
dican una mayor capacidad de gestión y autonomía en todos los aspectos de la vida política. Cuando el joven monarca asume las riendas del poder, en 1325, su gobierno se caracteriza por una marcada política filojudía. Con la idea de restablecer el sistema fiscal judío, el soberano Alfonso XI restaura en las cortes de Valladolid de $1325^{32}$ la legislación filojudía de Sancho IV y Alfonso X, que ampara las deudas de los judíos, anulando los privilegios de los obispos y clérigos sobre la excomunión por causa de una deuda no pagada.

Pero, al cabo de los años, el monarca tiene que replegarse a las exigencias y presiones de las cortes de Castilla. En 1329 salta al primer plano de la actualidad política la hostilidad hacia los prestamistas judíos, a los que se les acusa desde los organismos municipales de manipular los contratos de crédito, incrementar el valor real de las prendas pignoradas y la cuantía del dinero prestado, exigiendo cantidades superiores a las pactadas. Sin embargo, tras las acusaciones antijudías se embozan las pretensiones de los concejos urbanos por hacerse con el control de las escribanías. Para frenar los abusos de los contratos crediticios, pero en mayor dimensión para acceder a las peticiones de los municipios, Alfonso XI vincula a los escribanos cristianos de los concejos la redacción de los documentos legales que los judíos deben utilizar en las transacciones comerciales, anulando de un plumazo las escribanías judías. Así, la corona sujeta la redacción de los contratos comerciales judíos a la dirección de las escribanías cristianas de los municipios.

Las reformas administrativa y económica emprendidas por el dignatario regio afectan seriamente a la comunidad judía de Béjar. El 5 de enero de 1330 el soberano de Castilla extiende un privilegio regio en virtud del cual concede al escribano Alfonso Pérez de Valladolid autoridad oficial para redactar los contratos prestatarios de los judíos y cristianos bejaranos, concediendo al alcalde de la villa la misión de entregar las deudas que los cristianos tienen que satisfacer a los judíos ${ }^{33}$.

AMB, I.E. 2.11.

33 AMB, I.E. 1.7. 
En 1396, Diego López de Estúñiga recibe en propiedad el señorío de Béjar con todas sus rentas, incluidas la cabeza de pecho y pedido judío y las rentas de las alcabalas de la carne y vino judiego, pero en este documento no consta el juramento de fidelidad de los judíos de la aljama de Béjar al nuevo señor de la tierra. Por el contrario, cuando Pedro de Zúñiga recibe de la corona la ciudad y tierra de Trujillo, los judíos de la aljama trujillana prestan testimonio de fidelidad en reconocimiento de señorío, en noviembre de $1440{ }^{34}$. Dos años después, en 1442, la corona trueca a Pedro de Zúñiga la ciudad y tierra de Trujillo por el señorío de Plasencia. En enero de ese mismo año Semuel Albelia y Abraham Truchas, de la aljama judía de Jaraíz de la Vera, tierra de Plasencia, prestan juramento de fidelidad al conde Pedro de Zúñiga en señal de posesión y señorío, pero no hay testimonio de los judíos de la aljama de Plasencia ${ }^{35}$.

\section{LA JUDERÍA: PARROQUIA DE SAN GIL}

Siguiendo la costumbre de los reyes de Castilla y León, es de suponer que a principios del siglo XIII el monarca Alfonso VIII asignase a los judíos de Béjar una zona urbana para acomodar la judería. A finales del siglo XII, Alfonso VIII establece una judería en Plasencia, citada en el fuero. Pero en el de Béjar no hay ninguna mención a la judería.

Sobre el espacio urbano ocupado por los judíos bejaranos en los dos primeros siglos de su existencia disponemos de escasas noticias. En 1364, un judío de la villa de Olmedo vive en el barrio de San Juan, cuya casa linda con la vivienda llamada «del Pellicón» ${ }^{36}$ :

Unas casas con sus corrales quel dicho Ferrand Blázques avía aquí en la dicha villa a la collaçión de Sant Iohán, las quales casas llaman

34 H. BeInart, Trujillo, A Jewish Community in Extremadura on the Eve of the Expulsion from Spain (Jerusalén 1980) doc. 2, pág. 123.

${ }^{35}$ Véase mi libro electrónico Historia de los judios de Plasencia y su tierra: I. De los origenes a la Inquisición, siglos XII-XVII, II. Colección Diplomática (1187-1823) (Sevilla 2001) doc. 70.

36 Archivo Parroquial El Salvador [= APES], «Donación por Sancha Blázquez al cabildo de unas casas sitas en la colación de San Juan», editado por A. MARTíN LÁZARO, «Colección diplomática de la iglesia del Salvador de la ciudad de Béjar», RCJS 4 (1921) doc. 13, págs. 113-115. 
de Pellicón, de que son linderos de la una parte casas de bodega e corral de Gil Blásquez, hermano del dicho Ferrand Blásquez, e de la otra parte casas e corral de don Mosé, judío de Olmedo, e de la otra parte las calles del Rey.

En la relación de propiedades donadas en 1395 por Miguel Sánchez Yanguas, arcediano de Plasencia y Béjar, al cabildo de la iglesia catedral de Plasencia para manumitir su capellanía de misas, menciona la judería ${ }^{37}$ :

[Las] casas en que mora don Ça Doño que son a la judería, que han por linderos de la una parte casas de Antón Martínes e de la otra parte casas de Iohán Lópes, escribano.

Otras casas a la judería que fueron de Alonso Gil, clérigo de Santo Domingo, que han por linderos casas del benefiçio de Bartolomé Ferrándes e casas del fijo de Françisco Martínes, clérigo de Sant Pedro.

Otras casas que son a la calleja do mora don Ça Taytaça, que an por linderos casas de Diego Ferrándes Tarejo e casas de Garcí Muños.

Otras casas que son a la cal de Mansiella que fueron del dicho Alonso Gil, e que han por linderos casas del cabillo e casas de Pedro Sánches, carnicero.

Al hilo del texto documental de 1395, el cabildo de la iglesia catedral de Plasencia es propietario de varias viviendas en la judería de Béjar, una de las cuales arrienda a don Ça Doño. Don Ça Taytaça ${ }^{38}$ reside en una casa del cabildo ubicada en una calleja. Asimismo, un escribano del concejo, un clérigo de la iglesia parroquial de San Pedro y otros cristianos residen en la judería. El clérigo Alonso Gil tiene una casa en la judería y otra en la calle Mansilla, parroquia de San Juan, que dona al cabildo placentino.

37 ACP, sin catalogar.

38 En la relación de los judíos vecinos de Valladolid hay un Abrahán Taytaçag; véase A. C. MERChÁn FERnÁndeZ, Los judios de Valladolid. Estudio histórico de una minoría influyente (Valladolid 1976) pág. 129. 
Otro documento, éste de 1444 , relaciona las propiedades que el cabildo de la iglesia catedral de Plasencia posee en Béjar, las cuales arrienda a Juan de Oviedo y Mari Sánchez, su mujer ${ }^{39}$ :

Unas casas que son a Traseriego ${ }^{40}$ con su corral e bodega que han por linderos calles de conçejo.

Otra casa pequeña en que mora Juan Martínes, texedor, linderos casas de Juan Ferrándes, clérigo, e de Estevan Miguel, e casas de Salamón Fitero $^{41}$, e la calle de conçejo.

Otras casas donde mora la fija de Juan Mançebo a la collaçión de Sant Juan, en la calle de Mansilla, linderos casas de Gonçalo Alfonso e casas de la muger de Alfonso Gómes Cabrero.

En este Memorial de propiedades, más impreciso que el anterior, no se cita la judería, pero sí una casa alquilada en la calle Mansilla. Creemos que la casa de Traseriego o Trasediego y «la casa pequeña» podrían tratarse de una adquisición reciente.

Primeras conclusiones. Entre los años de 1364 y 1444 la judería de Béjar conforma un espacio urbano abierto en el cual conviven judíos, clérigos y cristianos. No funciona ningún apartamiento judío en estas fechas. Es muy posible que la judería se estableciese intramuros de la villa desde los primeros días de su asentamiento, como hemos documentado en Plasencia ${ }^{42}$. Pero todavía no hemos hallado ningún texto anterior a esa fecha que identifique el distrito eclesiástico de la

\footnotetext{
39 Archivo de la Catedral de Plasencia [= ACP], Actas del Cabildo Catedralicio [=ACC], «Libro primero viejo: 1399-1453», fols. 105-105v; hay copias en ACP, ACC, «Traslado auténtico de Actas Capitulares de los años de 1399 hasta el de 1453», fols. 272v-274.

40 «Yten queda por la dicha feligressía de Santa María el barrio que diçen de Trassediego, ques arraval desta villa, questá entre las puertas de Alonso López e Borroneyla [sic], desta manera: de cómo viene a la puerta de Alonso López por allí adelante hasta las casas que al presente son de Melchor López, clérigo, por una açera y otra parte, e por la parte de avaxo está sanct Andrés y entra dentro el hospital de Santandrés, exçeto que la cassa de Hernán Domínguez queda metida en la perrochia de sant Salvador» (AMB, I.E. 4.3: «Expediente de demarcación de las iglesias parroquiales de Béjar efectuadas por el obispo de Plasencia (1562)», fols. 2-2v).

${ }^{41}$ Fitero, persona que hace fita, tejido estrecho que sirve para adornar o atar.

42 Véase mi trabajo «Documentos sobre los judíos de Plasencia en el Archivo Catedralicio (1411-1492)», Sefarad 59 (1999) págs. 53-76.
} 


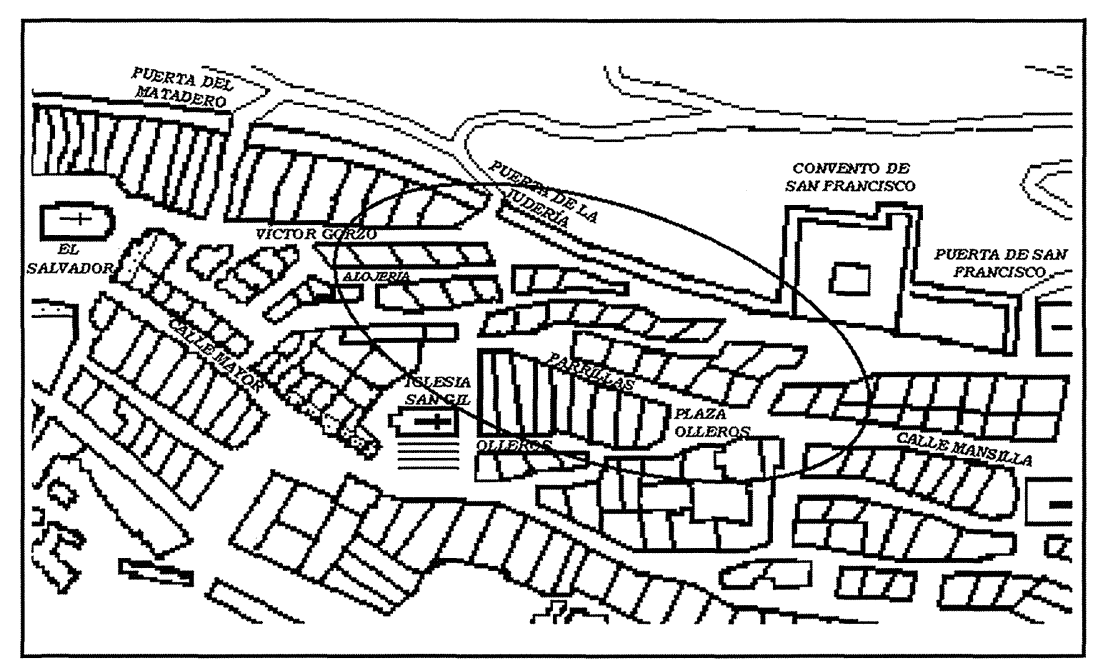

Fig. 1. Judería de Béjar (s. XIV y Xv). 
judería. Solamente tenemos los datos de un judío que vive en el barrio de San Juan, varios en la «judería» y en otro en una «calleja».

Sigamos exhumando documentos conforme a su cronología para precisar con mayor rigor histórico la situación geográfica de la judería en el callejero urbano de Béjar.

En el Libro de cuentas y relación de bienes inventariados a la muerte del conde de Béjar, Pedro de Zúñiga, en 1454, se establecen dos zonas urbanas claramente diferenciadas: las casas que posee el conde en el área urbana de la Alcaicería y las «otras casas que vuestra merçed tiene en la dicha villa fuera del Alcaçería». Fuera del perímetro urbano de la Alcaicería, el conde Pedro de Zúñiga posee quince edificios diseminados por las barriadas de San Gil y San Juan, de los cuales relacionamos los enclavados en la judería, y otros de interés ${ }^{43}$ :

la casa de la fragua que son en la judería

las casas en que solía morar el Coén que son en la judería, a la puerta donde van a Sant Françisco CLXXX las medias casas que son enfrente de la sinoga LV la meytad de las casas de la fragua, está en ella bonbarda, e la otra meytad rinde

Según este documento, el Cohén vive en una calle, o travesía, que conduce al convento de San Francisco. Podría tratarse de la calle Quebradilla, que nace en la intersección de Parrillas con Mansilla, o quizás de la Travesía de Parrillas. En cualquier caso, el documento establece la judería en el barrio de San Gil, muy cerca del conventual de San Francisco.

También menciona el texto la existencia una fragua en el interior de la judería. El «Memorial de la fasienda del conde mi señor», elaborado también en 1454, cita once casas, en lugar de quince, cuya

43 AHN, Sección Nobleza. Osuna, leg. 215, núm. 10/1: «Libros que contienen cuentas y relación de los bienes que quedaron del conde de Plasencia don Pedro de Zúñiga, 1454», fols. 222-222v. 
relación, mucho más aséptica que la anterior, nos aporta, no obstante, noticias complementarias sobre los edificios condales ${ }^{44}$ :

las casas de la fragua,

las casas en que solía morar el Ancho que son en la Canaleja, otra meytad de casas que son en la Canaleja e son la otra meytad del concejo,

la meytad de las casas de la fragua, çerca de palaçio, está la lonbarda grande, e en la otra meytad mora Alonso Péres.

En 1455 tenemos conocimiento del funcionamiento de dos casas de la fragua en la villa de Béjar, ambas propiedad de la familia Zúñiga, situadas fuera de la Alcaicería, una de ellas en la judería y otra «çerca de palaçio». Se refiere al palacio nuevo cuyo inmueble se rehabilita en el siglo XVI como convento dominico de la Piedad, sito en la Plazuela de San Gil ${ }^{45}$, hoy sede del Casino Obrero. Por consiguiente, el área del palacio nuevo, en la Plazuela de San Gil, está fuera del perímetro de la judería.

En 1457, la familia Zúñiga arrienda a Mosé Amigo Morenillo, a través de Pedro Martínez Cocoque, la fragua de la judería por una renta anual de $250 \mathrm{mrs}$, registrada por Juan Gonzáles Espinosa en los libros de la casa de Béjar en setiembre de ese mismo año ${ }^{46}$.

Diez años después, el conde Álvaro I alquila a Yuçé Halas, su hermano Mosé Halas, Yuçé del Sobrado y Masaltón, su mujer, por una renta anual de $400 \mathrm{mrs}{ }^{47}$,

unas casas que se disen de la fragua que el dicho señor conde atiene [sic] en la judería desta dicha villa, y alindan de amas partes con casas de don Çag Amigo Blanquillo e por delante con calles públicas de conçejo.

44 AHN, Sección Nobleza. Osuna, leg. 215, núm. 10/2, fol. 70.

45 AHN, Sección Nobleza. Osuna, leg. 216, núm. 6/12: «en esta villa se vendió el palacio nuevo, que en él se hizo el convento de la Piedad, comprándolo los duques don Francisco y Doña Brianda para este fin, pues lo pagaron bien» (la noticia corresponde al archivero de la casa de Béjar, fray Liciniano Saez).

46 AHN, Sección Nobleza. Osuna, leg. 215, núm. 10/2, fol. 170.

47 AHN, Sección Nobleza. Osuna, leg. 216, núm. 6/4, recogido por C. CARrETE PARrondo, Fontes, doc. 83. 
Çag Cohén avala el contrato de arrendamiento con una casa que posee en la calle Parrillas y varias heredades:

unas casas que yo he e tengo en esta dicha villa en la collaçión de Sant Gil, a donde disen las Parrillas, que alindan con casas de Abrahán Abenaguar e de la otra parte con ferrenal ${ }^{48}$ de los herederos de Gómes Ferrándes, escrivano, e con la calle pública de conçejo. E más una viña que yo he e tengo en término desta dicha villa al Asomada ${ }^{49}$, camino de Navalmoral, que alinda con prado de Alfonso Ferrándes Nieto, e de la otra parte con viña de Garçía Sánches de la Fuente e Bartolomé Sánchez de la Fuente, vesinos desta dicha villa, e con camino de conçejo.

En la villa de Béjar, rabí Semuel es dueño de una casa con sus corrales y pertenencias, las cuales tiene en propiedad la duquesa de Béjar, María de Zúñiga, que dona al doctor Gonzalo Pérez en 1533 por los servicios prestados ${ }^{50}$.

El 23 de mayo de 1492, el zapatero don Semuel de la Tetilla decide exiliarse de Béjar. Antes de su partida vende a maestre Luis, cirujano $^{51}$,

unas casas que yo e tengo en esta dicha villa de Béjar a la judería, cabe la carneçería, que lindan e han por linderos de la una parte con casas del fijo del Tocho, e de la otra parte con casas de doña Lediçia, muger de Mosé Abeatar, e la delantera es calle de conçejo.

En una fecha imprecisa que abarca de finales del siglo XV a comienzos del XVI, el judeoconverso Diego de Cáceres compra ${ }^{52}$

unas casas de maestre Luys, que es en Béjar, a la carnesçería junto con el matadero, la qual vendió a Alonso del Puerto.

Según este texto, la carnicería de la judería tiene una dependencia anexa que desempeña la función de matadero. Hacia 1514, el con-

\footnotetext{
${ }^{48}$ Herrenal, terreno cercado sembrado de herrén, forraje de cereales para pasto, ubicado en el casco urbano.

${ }^{49}$ «La Asomada, en la cornisa existente entre la trinchera del ferrocarril y el vertedero municipal, al Oeste del Ventorro de Pelayo» (J. MuÑoz Domínguez, «La judería errante (XI)», pág. 8).

so AHN, Clero, libro 10629, fol. 62.

51 AHN, Sección Nobleza. Osuna, leg. 218, núm. 3/6, citado por C. CARreTE PARRONDO, Fontes, doc. 87.

52 AHN, Inquisición, leg. 4573/1, s. f.
} 
verso Alonso Pérez, perseguido por la Inquisición de Llerena, abandona su casa bejarana, que su hermano Gabriel Pérez traspasa a Diego González y éste a Juan de Salinas ${ }^{53}$. J. Muñoz Domínguez documenta que ${ }^{54}$

la carnicería [pública] formaba un todo con la alhóndiga, la cárcel y las casas del ayuntamiento, y que dicho conjunto de dependencias estaba en la Plaza, detrás [de] San Salvador.

Concretamente, sitúa el inmueble en la vivienda del soportal de la Plaza Mayor con las columnas de granito y los dos escudos blasonados de los Zúñiga. Así pues, a finales del siglo XV funcionan dos carnicerías en Béjar: la carnicería cristianega de la Plaza Mayor y la carnicería de la judería de San Gil, en la que el matarife judío sacrifica las reses siguiendo los preceptos del ritual mosaico.

Las comunidades judía y cristiana del obispado de Plasencia, en concreto las de Béjar, Plasencia y Trujillo, tienen carnicerías propias. Otra cosa bien diferente es que los cristianos se abastezcan en las carnicerías judías, o que las carnicerías cristianegas sean arrendadas por judíos, o tengan «cortadores de carne» judíos, como ocurre en Trujillo en el último tercio del siglo $\mathrm{XV}^{55}$.

A la vista de los documentos exhumados, la calle Parrillas y su Travesía, situadas en el distrito parroquial de San Gil, forman parte de la judería bejarana. Pero creemos que no son las únicas calles, como veremos en el siguiente epígrafe. Nos queda la duda de la calle Mansilla. No tenemos datos precisos sobre esta calle. Todo lo que sabemos por el momento es que en Mansilla vive un judío en el siglo XIV.

Con motivo de la reorganización y exclaustración por el obispo de Plasencia, Pedro Ponce de León, de las iglesias parroquiales de Bé-

53 AHN, Inquisición, leg. 4573/1, s. f.; véase mi trabajo «La Inquisición en el señorío de Béjar y sus consecuencias, 1514-1515», Revista de Estudios Extremeños 57/2 (2001) págs. 661-698: pág. 675 y doc. 1.

54 J. MUÑOZ DoMíNGUEZ, «La judería errante (III)», pág. 7.

55 Sobre las comunidades judía y conversa de Trujillo y su tierra estoy escribiendo un ensayo histórico; las fuentes proceden de los libros de actas del Archivo Municipal. 
jar, en 1562, las casas y calles de la iglesia de San Gil son absorbidas por las parroquias de El Salvador y San Juan, estableciéndose el límite jurisdiccional hacia la mitad de la calle Parrillas ${ }^{56}$, entre los números 29 y 31 -aún se conserva el sillar con la inscripción «SJ»-, cuyas iglesias se reparten el antiguo entramado urbanístico judío.

Algunos autores consideran, sin aportar ningún documento de archivo, que la judería bejarana está en el barrio de la Antigua, en la parroquia de Santa María. ¿Cómo surge esta inconsecuencia histórica? Hacia 1938, J. Muñoz García lanza una teoría, no contrastada por la documentación de archivo, que identifica la sinagoga con una casa de estilo mudéjar ubicada en la calle 29 de Agosto ${ }^{57}$. Del edificio sinagogal trataremos con mayor amplitud en otro apartado. Como la sinagoga suele encontrarse, por regla general, en la judería, el autor bejarano deduce que ésta se halla en el barrio de la Antigua, cuyo criterio comparten J. García Atienza ${ }^{58}$, C. García Martínez ${ }^{59}$ y

\footnotetext{
56 «Sanct Juan. La yglessia de Santo Domingo e Sanct Nicolás e de Sanct Miguel las reducimos a lass yglessias parrochial de señor Sanct Juan, a la qual adjudicamos por feligressía e perrochianos de la dicha yglessia desde el albanar e caño de serviçio de agua que sale por la çerca e muros desta villa, por çima de la puerta de la Solana, donde se remató e acavó la filigressía e parrochia de San Salvador, por la çerca e muros adelante hasta la puerta de San Nicolás, e por allí ariva hasta la puerta de la Corredera, e de la puerta de la Corredera la çerca adelante a la puerta del Canpo Pardo a dar al monasterio de San Francisco, como ba la çerca hasta la huerta del dicho monesterio, donde viene a rematar el çircuito e deslinde de la perrochia de Sant Salvador, e por aquel derecho sube al corral questá junto a la cassa de Françisco Garçía Moreno, e de allí sale a la calle de las Parrillas, e sube la calle ariva hasta donde se parte la calle, e vuelve por unas peñas que allí están, por la calle que viene de arriva de Sant Françisco para San Gil, e va por la calle avaxo a dar a un corral que posee Françisco de la Torre, e de allí dexa el viaxe desta calle que va para la yglesia de San Gil, e toma la otra calle que va arededor [sic] de aquel corral questá çercado, e sale a la calle Mayor e la cruxa e passa la callexa avaxo a dar al dicho padrón» (AMB, I.E. 4.3 , fols. $5 v-6 v$ ).

57 J. MuÑoz GARCíA, «Epigrafía bejarana. La lápida hebrea», Béjar en Madrid [= BM] 22 (26 marzo 1938) págs. 5-6: pág. 6.

58 J. García Atienza, Caminos de Sefarad (Barcelona 1994) pág. 120; reedición de Guía de la España judia (Madrid 1978).

59 C. García Martínez, Un paseo por el Béjar del siglo XVIII (Béjar 1987) págs. 64-65; ID., Béjar en su Historia, 1 (Salamanca 1993) pág. 85.
} 
J. A. Sánchez Paso ${ }^{60}$. J. L. Lacave ${ }^{61}$ y A. Avilés Amat ${ }^{62}$ navegan entre dos aguas. En cambio, C. Carrete Parrondo, M. ${ }^{a}$ F. García Casar ${ }^{63}$, J. C. Aguilar Gómez, M. ${ }^{a}$ C. Martín Martín ${ }^{64}$, J. Muñoz Domínguez ${ }^{65}$, y nosotros mismos, situamos la judería en la parroquia de San Gil.

\section{LA PUERTA DE LA JUDERÍA O LA PUERTA NUEVA}

A. Martín Lázaro publica un extracto del Libro de regla del cabildo eclesiástico de Béjar de 1467, exhumado del archivo parroquial de El Salvador ${ }^{66}$, en el que expone el orden protocolario en el que deben desfilar las cruces parroquiales en la procesión de San Medel. Así las cosas, las cruces de las iglesias de San Juan, San Nicolás y San Miguel enfilan por la puerta de San Francisco, y las de las iglesias de El Salvador, San Gil y San Andrés por la puerta de la Judería, reuniéndose en el puente de San Albín. De modo que, en el siglo XV, en el tramo de la muralla norte que se extiende desde la iglesia de El Salvador hasta el monasterio de San Francisco, hay dos puertas de acceso: la puerta de San Francisco ${ }^{67}$ (barrio de San Juan) y la puerta de la Judería (barrio de San Gil).

60 J. A. SÁnchez Paso (ed.), Crónica burlesca del emperador Carlos V. Don Francés de Zúñiga (Salamanca 1989) pág. 19.

61 J. L. LACAVE, Juderias y sinagogas españolas (Madrid 1992) pág. 267.

62 A. Avilés Amat, Judios de Béjar, pág. 27.

${ }^{63}$ M. ${ }^{\mathrm{a}} \mathrm{F}$. GARcía CASAR, El pasado judio de Salamanca, pág. 135.

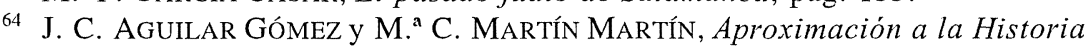
de Béjar, págs. 89-90.

65 En su trabajo «La judería errante».

${ }^{66}$ A. MARTín LÁZARO, «Para la historia eclesiástica de Béjar y su comarca. Libro de regla del cabildo eclesiástico de Béjar», Ofrenda a la santísima virgen del Castañar 2 (Béjar 1963) págs. 117-175: pág. 166, tomado del APESB, «Libro de regla del cabildo eclesiástico de Béjar (1467)».

67 La puerta de San Francisco se encontraba entre el monasterio franciscano y la iglesia de Santo Domingo. Dicha iglesia se levantaba en el bloque de pisos de la calle Ronda de Navarra números 11 y 13. En 1502, García de Oviedo vende una tierra al monasterio de San Francisco que linda «con la calle o camino que va a la puerta de Canpo Pardo, e de la otra con tierra de la dicha iglesia de Santo Domingo, e de la otra con una tierra que allegan a la çerca nueva que agora se haze que disen ser del dicho monesterio de señor Sant Françisco», AMB, I.E. 5.33. 
En la reordenación jurisdiccional de las iglesias de la villa bejarana efectuada en 1562, la parroquia de San Juan absorbe una parte del territorio de la iglesia de San Gil, con los edificios y casas emplazados en ${ }^{68}$

la puerta del monesterio de San Françisco, e de allí adelante por la çerca a la puerta Nueba de la villa, e de allí por la çerca a la puerta del Matadero de la villa, e de ay a la fortaleça e palacio del duque ${ }^{69}$.

Así pues, en 1562, hay tres vanos en el lienzo de la muralla: la puerta de San Francisco, la puerta Nueva y la puerta del Matadero, esta última construida en la primera mitad del siglo XVI. Creemos que en 1521 todavía no existe la puerta de la carnicería del matadero. Ese mismo año, el concejo adquiere una casa en la Plaza Mayor a Pedro Sánchez y su mujer Beatriz, posiblemente para ampliar las dependencias municipales ${ }^{70}$,

ques una entrada por un portal e una cámara junto a las carnicerías desta villa, linda la entrada y portal e cámara con las casas del consistorio e carnicerías.

Hacia 1578, enfrente del viejo consistorio, extramuros, el concejo tiene previsto instalar el nuevo matadero municipal, para lo cual adquiere una casa a Esteban de Tórtoles ${ }^{71}$,

a do dicen la puerta de la carniçería del matadero... y os la vendemos pa matadero de las carniçerías de la dicha villa.

Es evidente que ha desaparecido de los registros documentales del siglo XVI la denominación «puerta de la Judería», lo que no significa que haya sido demolida. J. C. Aguilar Gómez y M. ${ }^{a}$ C. Martín

${ }^{68}$ AMB, I.E. 4.3, fol. 5.

69 Se refiere al alcázar, residencia de los duques de Béjar en el siglo XVI.

70 AMB, I.E. 5.57: «Carta de venta para el concejo de la villa de Béjar de las casas que conpraron de Pedro Sánchez turco, vecino de Béjar, 1521», en el catálogo del archivo municipal dice 1527; citado por J. MuÑoz DomíngueZ, «La judería errante (III)», pág. 7

71 AMB, I.E. 5.67: «Venta a fabor de la villa. Otorgó Esteban de Tórtoles y su mujer, vecinos de Montemaior, de unas casas con corral a do dizen la puerta de la carnizería del matadero ante Françisco de Camargo, escribano de Montemayor, año de 1578»; citado por J. MUÑoz DomíngUEZ, «La judería errante (III)», pág. 7. 


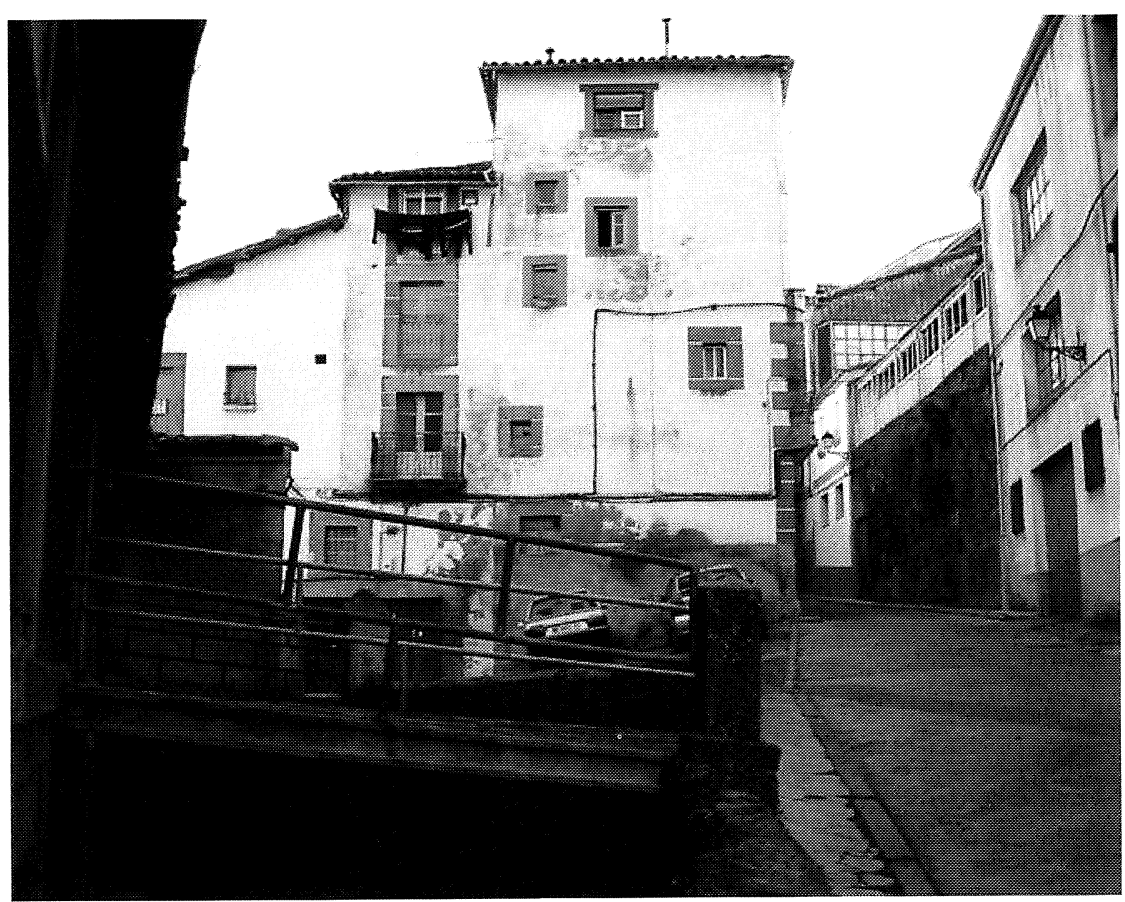

Fig. 2. Calle Parrillas, Judería de Béjar (s. XIV y Xv). 
Martín ${ }^{72}$ sugieren que la puerta de la Judería podría ser la puerta Nueva, que tiene salida a la «cuesta de los perros». Sin embargo, J. Muñoz Domínguez ${ }^{73}$ se inclina por la del Matadero. En nuestra opinión, la puerta de la Judería ha modificado su nombre por el de la puerta Nueva, puesto que siguen en pie las puertas de San Francisco y del Matadero. Su nombre actual, «Nueva», es una clara alusión a los cristianos nuevos que ocupan el barrio de la antigua judería. Por esta razón, el barrio judío cambia su nombre por el de barrio converso o nuevo. En realidad, la calle Barrionuevo es la de Víctor Gorzo, que nace en la puerta Nueva y comunica la Plaza Mayor con el convento de San Francisco.

Hacia 1727, Ventura de Lirios dibuja en un óleo las calles, plazas y patrimonio de la villa de Béjar, en la que ilustra la puerta Nueva -de la que actualmente se conserva medio arco tapiado-, así como el camino empedrado que desciende por la trasera del convento de San Francisco, y el camino de la puerta del Matadero, hoy puerta del Puente de Alcolea. No sabemos la fecha de demolición de la puerta de San Francisco, que no se conserva en la actualidad.

Como la calle Víctor Gorzo -Barrionuevo- nace en la puerta de la Judería, seccionando por la mitad la calle Alojería en su camino hacia la calle Parrillas, es de suponer que el primer tramo de estas dos arterias urbanas también formaría parte del barrio judío de Béjar.

En los estudios de investigación que estamos realizando sobre las juderías y sinagogas de la provincia de Cáceres, la puerta de la Judería se construye en el lienzo de la muralla a modo de postigo o puerta de acceso: el postigo de la judería apartada de la Mota de Plasencia (1412) ${ }^{74}$, el arco del Cristo o puerta de la Judería de Cáceres (siglo XIV), la puerta de la Villa, de Cuatro Calles o de la Ciudad de Coria ${ }^{75}$ (siglo XIV), y la puerta de la Judería de Béjar.

72 J. C. Aguilar Gómez y M. ${ }^{a}$ C. Martín Martín, Aproximación a la Historia de Béjar, pág. 90.

73 J. Muñoz Domínguez, «La judería errante (III)», pág. 7, y «La judería errante (X)», pag. 11 .

74 En mi trabajo «Documentos sobre los judíos de Plasencia», págs. 53-76.

75 Véase M. DE Hervás, « La judería y sinagoga de Coria en la documentación del Archivo Catedralicio: siglos XIV y XV », Sefarad 61 (2001) págs. 91-125. 


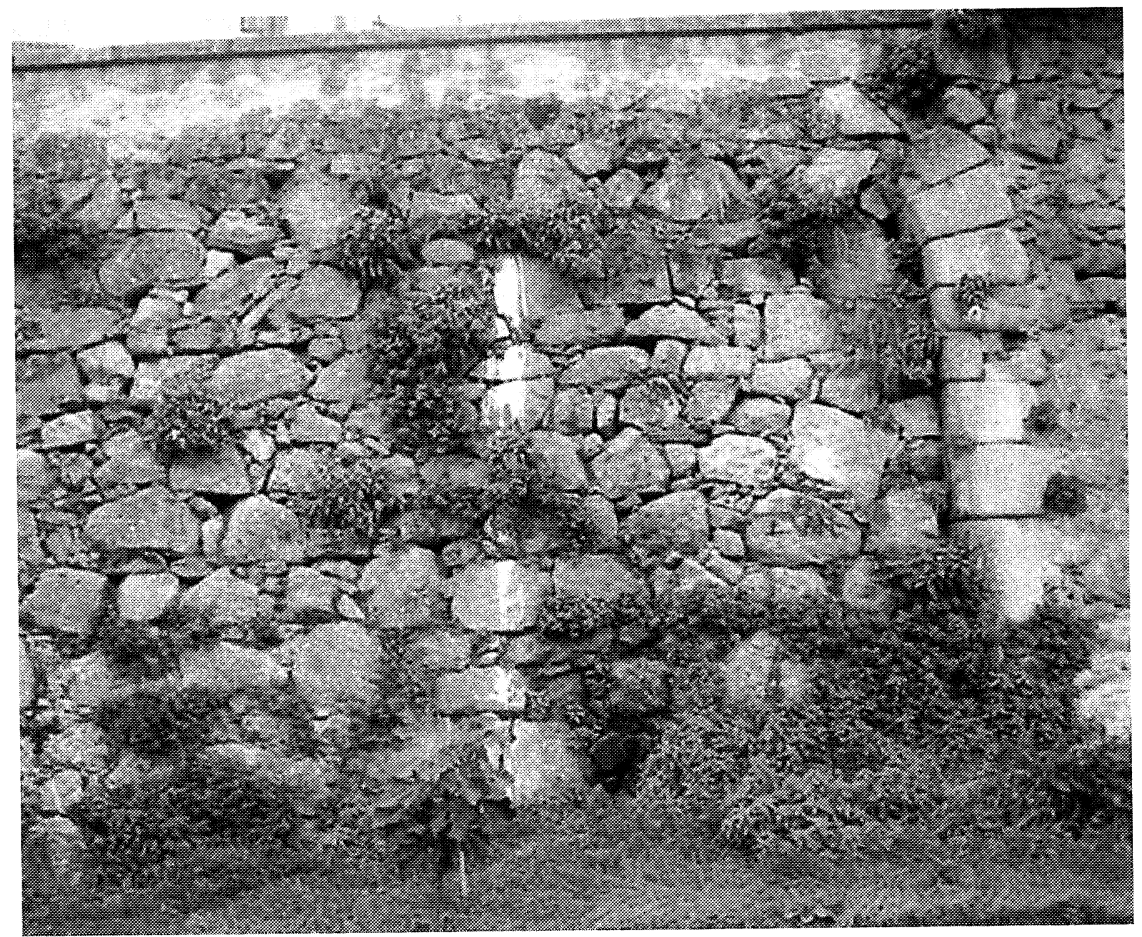

Fig. 3. La puerta de la Judería (s. XIV), puerta Nueva (s. XVI-XVIII). En la actualidad, tapiada. 
8. OtRos espacios uRbanos JUdíos: la AlCAICERÍA y la CALle MAYOR

No todos los judíos de la aljama de Béjar viven en la judería de las parroquias de San Gil y San Juan. Algunos judíos prefieren alojarse en otros espacios urbanos más céntricos, como la Alcaicería. Tradicionalmente se sitúa el foco comercial de la Alcaicería en la Plaza de San Juan Bosco. Sin embargo, escrituras recientes exhumadas por J. Muñoz Domínguez identifican «la Alcayçería o Carrera» con la calle Rodríguez Vidal, próxima a la Plaza Mayor ${ }^{76}$.

En el fuero de Béjar, la Alcaicería aparece como un espacio abierto destinado a foco comercial propiedad de la corona, alquilado a los mercaderes y comerciantes para instalar sus tiendas ambulantes (rúbs. 860 y 877). Desde 1396 la zona urbana de la Alcaicería pertenece a la casa de Béjar, cuyo solar arrienda todos los años. En $1454^{77}$

rendieron más las ayudas de los paños del alcaçería año de LIII con los suelos de las ayudas de la plaça de la feria que se fase cada año en la dicha villa.

VIU LXXV

Otro apunte económico fechado el mismo año expresa ${ }^{78}$ :

otrosy, rindieron los suelos de las tiendas del alcaçería e las tiendas de joyeros e espeçieros en la feria del año pasado de [IU CCCC] LIII, VIU $\mathrm{CXCV}$, e estos mesmos puede rendir en cada año poco más o menos.

En 1491 Diego Ferrándes del Barco es fiador de don Isaque Albuer en la renta de la alcabala del ganado de la feria perteneciente al duque de Béjar. Como Isaque Albuer no puede amortizar la deuda fiscal, el duque Álvaro II le confisca una casa que tiene en la Alcaicería. Diego Ferrándes cobra la deuda de la fianza con la casa de don Isaque Albuer que le entrega el duque de Béjar. Diego Ferrándes del Barco y rabí Haym Abenmuça venden la casa por

76 J. MuÑoz Domínguez, «La judería errante (IV)», pág. 7.

77 AHN, Sección Nobleza. Osuna, leg. 215, núm. 10/2, fol. 70v.

78 AHN, Sección Nobleza. Osuna, leg. 215, núm. 10/1, fol. 222. 
$13.000 \mathrm{mrs}$ a Blasco de Madrigal ${ }^{79}$. La vivienda de don Isaque Albuer linda con la casa de rabí Haym Abenmuça y la de rabí Jacob Çarfati. Es muy posible que Haym Abenmuça sea pariente del reputado escritor y poeta bejarano Hayyim ibn Musa.

Otro de los espacios urbanos ocupados por los judíos es la calle Mayor. El 4 de junio de 1492 don Isaque Agi, o Agui, y su mujer doña Oruçeti venden una casa en la calle Mayor a Diego García, cura de la iglesia parroquial de San Juan, por $10.155 \mathrm{mrs}$. La vivienda linda por los laterales y trasera con tres casas de rabí Ça, físico, y por delante con la calle Mayor. En realidad, el clérigo de San Juan paga al matrimonio judío un justo, cinco doblas, varios cruzados - la cifra figura en blanco en el contrato de venta-, tres castellanos y 132 reales de plata ${ }^{80}$.

La calle Mayor es la arteria urbana principal de Béjar. Se extiende desde la Puerta del Pico hasta la desaparecida Puerta de Ávila, surcando la villa de extremo a extremo. A lo largo de la historia, la arteria principal recibe distintos nombres, según el tramo urbano por donde transcurre. Así, la vía urbana nace en la Puerta del Pico con el nombre de calle Mayor de Santa María -hoy, 29 de Agosto-. Atraviesa la Plaza de San Juan Bosco y la Alcaicería o Carrera -hoy, Rodríguez Vidal-. Y desemboca en la Plaza Mayor. En esta plaza nace la calle Mayor -hoy, Mayor de Pardiñas-, que discurre en paralelo a las calles Barrionuevo y Parrillas y desemboca en el pórtico de la iglesia parroquial de San Gil -hoy, Museo de Mateo Hernández-, continúa en dirección a la Corredera con los nombres Rodulfo Sánchez Ocaña y Mayor de Reinoso hasta su desembocadura en la desaparecida puerta de la Villa o de Ávila ${ }^{81}$. Así pues, Isaque Agui y doña Oruçeti residen en la calle Mayor, posiblemente en el tramo urbano próximo a la judería de la calle Barrionuevo.

79 AHN, Sección Nobleza. Osuna, leg. 218, núm. 3/7; citado por C. CARrete PARRONDO, Fontes, doc. 85.

80 AHN, Sección Nobleza. Osuna, leg. 218, núm. 3/8; recogido por C. CARRETE PARRONDO, Fontes, doc. 88.

81 J. L. Majada NeIla, Historia de Béjar, pág. 121. 
A modo de corolario, esquematizamos el callejero y patronímico de los judíos que residen en la villa de Béjar:

Judería:

1395, Ça Doño.

1457, Mosé Amigo Blanquillo.

1467, Çag Amigo Blanquillo, Yuçé Halas, su hermano Mosé Halas, Yuçé del Sobrado, su mujer Masaltón, don Çage Amigo Blanquillo.

1491, Mosé Abenatar y doña Lediçia.

1492, Don Semuel de la Teçilla.

Puerta de la Judería:

1454, El Cohén.

Calleja ¿Travesía de Parrillas?:

1393, Don Ça Taytaça.

Calle Parrillas:

1467, Çague Cohén y Abraham Abenaguar.

Calle Mayor:

1492, Don Isaque Agi, su mujer doña Oruçeti y rabí Ça.

Parroquia de San Juan (¿Mansilla?):

1367, El judío de Olmedo

Lugar desconocido:

1444, Salamón Fitero

1492, Rabí Semuel, físico

Alcaicería:

1491, Don Isaque Albuer, rabí Haym Abenmuça y rabí Jacob Çarfati. 
A tenor de los textos reseñados, la judería primitiva de Béjar se establece en la calle Parrillas y, quizás, Mansilla. El incremento demográfico experimentado en el siglo XV pudo desbordar los límites de la primitiva judería extendiéndose por zonas de las calles Alojería y Olleros.

En la antigua plazuela de Peñuelas, hoy Plaza de Olleros, confluencia de las calles Parrillas, Mansilla, Quebradilla y Mateo Hernández, F. Cantera Burgos señala tres letras hebreas que no hemos podido localizar ${ }^{82}$ :

En el solado de la Plazuela-calle llamada de las Peñuelas, y junto a hermosa lápida escudada de un personaje cristiano medieval, se hallan dos lonchas de piedra granítica que parecen presentar restos de letras hebraicas.

\section{LA SINAGOGA}

Al cronista oficial de Béjar Juan Muñoz García le cabe el honor de haber contribuido con notable acierto en el proceso de investigación, transcripción -con algunos errores paleográficos- y exhumación de textos documentales, muchos de ellos inéditos, relacionados con la historia de la comunidad judía bejarana. Sin embargo, J. Muñoz García ha lanzado una tesis, no contrastada con la documentación de archivo, que ha devenido en arquetipo, como la supuesta sinagoga de la calle 29 de Agosto.

En 1918 Muñoz García escribe sobre «una casa vieja» con una puerta muy deteriorada y un dintel de madera de influencias románicas situada en la calle 29 de Agosto, de la cual había dado noticia anteriormente el arquitecto Guitart. Según J. Muñoz García, «el primitivo objeto de su edificación debió ser para instalar en ella la aljama de los mudéjares que habitaran Béjar y su comarca» ${ }^{83}$.

En la fotografía que ilustra el artículo apreciamos una puerta de dos hojas de madera, una de ellas, la de la derecha, con un portillo

82 F. Cantera Burgos, Sinagogas españolas, pág. 175.

83 J. MuÑoz GARCíA, «Una casa vieja», BM 2 (1 enero 1918) págs. 5-6. 
ojival. El sistema constructivo del edificio se enmarca en la arquitectura popular entramada de madera y ladrillos de adobe, que caracteriza a los pueblos de las estribaciones del sistema de Gredos. La primera planta de la supuesta sinagoga bejarana sobresale ligeramente sobre el piso inferior, rematada con tres hileras de vigas escalonadas adornadas con numerosos canecillos tallados con rostros humanos y otras figuras ${ }^{84}$.

En 1938 el cronista bejarano ofrece una nueva visión de la casa mudéjar, que vincula con la sinagoga, pero sin aportar sus fuentes de archivo. El autor bejarano relata lo siguiente ${ }^{85}$ :

La fachada de la vieja sinagoga es de estilo mudéjar con mucha influencia de arte románico y conserva las puertas de madera de castaño que tenía hace más de cuatro siglos, cuales puertas están guarnecidas con herrajes, y la izquierda tiene postigo de traza ojival.

F. Cantera Burgos, que visita la supuesta sinagoga en $1940{ }^{86}$, consolida la propuesta de J. Muñoz García. Pero en la visita de junio de 1954 confiesa que en el supuesto edificio sinagogal «no hemos hallado vestigios de especial interés arqueológico desde nuestro punto de vista» ${ }^{87}$.

La teoría de J. Muñoz García cobra proyección al difundirse en los medios de comunicación, contribuyendo a la consolidación del artificio. En 1969, el corresponsal bejarano del periódico salmantino El Adelanto informa sobre el mal estado de conservación de la supuesta sinagoga, destacando las labores de reconstrucción que tiene previsto acometer la Comisaría del Patrimonio Artístico Nacional. En palabras del corresponsal J. de F. ${ }^{88}$,

${ }^{84}$ Sobre los canes de madera del edificio véase J. MuÑoz Domínguez, «La judería errante (XX)», pág. 8.

85 J. MuÑoz GarCÍA, «Epigrafía bejarana», pág. 6.

${ }^{86}$ F. CANTERA Burgos, «De epigrafía hebraicoespañola», Sefarad 2 (1942) págs. 106-112.

87 F. Cantera Burgos, Sinagogas españolas, pág. 175.

${ }^{88}$ J. de F., «¿Hasta cuándo va a estar apuntada lo que fue sinagoga judía?», El Adelanto (Salamanca, 25 octubre 1969) pág. 6; citado por C. CARrete PARronDo, Fontes, doc. 89 nota 1. 
esta portada, que hace unos treinta años se conociera con el número 55 de la calle de 29 de Agosto -entonces la numeración se hacía al contrario que hoy existe- es la de una sinagoga judía, que data de antes de la expulsión de los árabes [sic] por los Reyes Católicos, y por ello es de estilo mudéjar con ciertas influencias del románico en los canecillos de madera que muy bien pueden apreciarse en la fotografía que apuntamos, pese a que la cal y la arena hayan roto todas las demás reliquias que aparecían sobre el marco superior de la puerta, como así es.

La propuesta de F. Cantera Burgos, que toma de J. Muñoz García, es divulgada por J. García Atienza en 1978 y $1994{ }^{89}$, M. ${ }^{a}$ F. García Casar en $1989^{90}$ y J. L. Lacave en $1992^{91}$. Sin embargo, Lacave suprime la referencia de la sinagoga bejarana en su Guía de la España judía ${ }^{92}$ ¿ ¿Fue porque albergó dudas sobre la verdadera identidad del edificio sinagogal?

¿Qué nos dicen las fuentes de archivo? En capítulos precedentes hemos recogido un texto que documenta la ubicación de la sinagoga fuera del perímetro de la Alcaicería. El Libro de cuentas de la hacienda del conde Pedro de Zúñiga detalla «las medias casas que son enfrente de la sinoga» ${ }^{93}$.

También disponemos de otros documentos que refieren el extorsionamiento y deterioro del inmueble sinagogal inmediatamente después de producirse su abandono forzoso por los judíos en el verano de 1492. Por las declaraciones de un bejarano -publicadas por C. Carrete Parrondo ${ }^{94}$-, sabemos que dos vecinos de la villa «tomaron de la sinoga trezientas tejas que fueron menester» para arreglar las dos viviendas que tenían alquiladas al duque de Béjar. También confiesa el declarante que «un moço de Carlos tomó un día

\footnotetext{
89 J. García Atienza, Caminos de Sefarad, pág. 120; revisión de su Guía judia de España, Madrid 1978.

90 M. ${ }^{a}$ F. Garía CASAR, El pasado judio, pág. 135, que toma de Cantera Burgos.

91 J. L. LACAVE, Juderías y sinagogas, pág. 267.

92 J. L. LACAve, Guía de la España judia, pág. 65.

93 AHN, Sección Nobleza. Osuna, leg. 215, núm. 10/1: «Libros que contienen cuentas y relación de los bienes que quedaron del conde de Plasencia don Pedro de Zúñiga, 1454», fol. 222v.

94 AHN, Sección Nobleza. Osuna, leg. 266, núm. 74, editado por C. CARrete PARRondo, Fontes, doc. 89.
} 
un madero para un pesebre de la sinoga», puntualizando este mismo testigo que «halló un día dos maderos caydos en la sinoga y que los hezo traer a su casa» ${ }^{95}$.

El Interrogatorio elaborado por la casa de Béjar el 23 de junio de 1495 sobre el patrimonio abandonado por los judíos en el señorío confirma la destrucción de «las casas de la synoga desta villa de Béjar» ${ }^{96}$.

Así pues, albergamos serias dudas sobre el estado de conservación en que se encuentra la supuesta sinagoga del barrio de la Antigua en 1938, como razona J. Muñoz García, toda vez que la cubierta del edificio judío es saqueada y la estructura de madera desmantelada por vecinos de la villa con la autorización de Toribio López ${ }^{97}$, recaudador y familiar del duque de Béjar, Álvaro II.

Después de los atropellos perpetrados en 1492, el edificio sinagogal queda abandonado, deteriorándose con el paso de las décadas hasta su total desaparición. En el auto de fe realizado en la villa de Béjar en 1588 por Diego Córdoba y Mendoza, inquisidor del tribunal de Llerena, un testigo declara que ${ }^{98}$

Gaspar Sánchez, tegedor, vezino de Béjar, fue testificado con un testigo barón de oydas que avía ocho años que todos los sábados llebava pan y una sardina por ofrenda, y el corral hera antiguamente sinoga.

Por consiguiente, en el último tercio del siglo XVI la casa de la sinagoga es un corral abandonado reducido a escombros de la que no queda ni la portada.

No solo la sinagoga es destruida. También corren la misma suerte los objetos litúrgicos del santuario y el mobiliario sinagogal. Así, «avía en la sinagoga desenueve o veynte lánparas en la sinoga entre

95 Véase nota anterior.

96 AHN, Sección Nobleza. Osuna, leg. 218, núm. 4/2, editado por C. CARrete PARRONDO, Fontes, doc. 94.

97 Toribio López es alcalde de la villa de Béjar en 1503; véase Archivo Municipal de Plasencia [= AMP], «Testimonio dado por Blasco Gil, escribano del número y ayuntamiento de estta ciudad, a 5 días del mes de febrero de 1592 años, de un pribilegio que tiene la ciudad para no pagar monedad forera», fol. 14.

98 AHN, Inquisición, leg. 1988, núm. 25. 
chicas y grandes» ${ }^{99}$. Se refiere a las lámparas perpetuas o de aniversario de muerte sustraídas del edificio en 1492.

El rollo sagrado de la Torá está adornado con objetos de plata valorados en más de 30.000 mrs: «la plata que tenían las Torás podían valer mas de treynta myll maravedís», las cuales rabí Haym Gascón recibe de la comunidad judía para amortizar una deuda judía a uno de los oficiales del rey.

Para cubrir los rollos sagrados de la Torá colocados en el armario sinagogal, la comunidad judía dispone de dos vestimentas o mantos de brocado, el mappah, que deposita en manos del judeoconverso Diego de Cáceres para pagar una deuda a Porcallo. Pero las dos piezas son requisadas por el alcalde bejarano Ambrosio de la Peña.

Es de suponer que desde los primeros días de su asentamiento en la villa, la sinagoga bejarana tuviese una sala oratorio para celebrar los oficios litúrgicos preceptivos. También pudo tener una sala anexa para albergar las sesiones del tribunal rabínico y la escuela. Sin embargo, el tribunal de arbitraje entre judíos y cristianos se asienta en la puerta de la alcazaba en lugar de la sinagoga (rúb. 871).

Como experto conocedor de la legislación judía, el rabino bejarano ejerce notable influencia espiritual sobre la sociedad de su tiempo. Encontramos un colectivo judío que goza de titulación rabínica en la aljama de Béjar. El célebre pietista rabí Hayyim ibn Musa (c. 1380), rabí Yudá de Castro (1478), rabí David de Castro, rabí Semuel Çerfati (1479), rabí Haym Abenmuça, rabí Jacob Çerfati (1491), rabí Yudá Cara, rabí Ça, rabí Yudá de Coca, rabí Haym Gascón y rabí David Abenverga (1492). Existe un rabí Haym documentado en 1453 que podría tratarse del célebre rabí Hayyim ibn Musa fallecido en 1460.

\section{LA NECRÓPOLIS}

Consumados los plazos del edicto de expulsión, en algunas ciudades y villas los católicos reyes donan las lápidas de las necrópolis

99 AHN, Sección Nobleza. Osuna, leg. 266, núm. 74; editado por C. CARRETE PARRONDO, Fontes, doc. 89. 
judías a los conventos de la orden de Santo Domingo, para reutilizarlas como material de construcción en las reformas de los santuarios. Así sucede en algunas comunidades judías del obispado de Plasencia, como Plasencia ${ }^{100}$ y Trujillo ${ }^{101}$.

Del cementerio judío de Béjar sabemos que en 1877 aparece en el interior de la explanada de la alcazaba una lápida sepulcral de granito de $1,65 \mathrm{~m}$. de longitud y $0,675 \mathrm{~m}$. de ancho, destacando la originalidad de los caracteres hebraicoespañoles, realizados a doble trazo. Esta inscripción, que procede del cementerio hebreo de Béjar, cuya ubicación ignoran las escrituras, ha sido fechada a finales del siglo XIII y principios del XIV ${ }^{102}$. La lápida contiene la siguiente leyenda conmemorativa ${ }^{103}$ :

Doña Fadueña, descanse en gloria gloriosa princesa en lo interior.

En la actualidad, la lápida epigráfica bejarana se conserva en el patio interior del Museo Sefardí de Toledo, reservado para las epigrafías hebreas hispanas. Hay una reproducción en el claustro del convento de San Francisco, rehabilitado para uso de Casa de la Cultura, Archivo, Biblioteca, etc.

En los últimos años circulan por la villa varias teorías que ubican el cementerio hebreo en la zona berrocosa próxima al puente de San Albín. Otros la emplazan al pie de la puerta de la judería ${ }^{104}$. En puridad, solo se tratan de teorías, válidas o no, que no están contrasta-

\footnotetext{
${ }^{100}$ En mi artículo «Documentos sobre los judíos de Plasencia», págs. 263-307, doc. 11/2, págs. 298-302; y en Los judios de Plasencia, docs. 191-193.

${ }^{101}$ Archivo General de Simancas [=AGS], Registro General del Sello [=RGS], (25 noviembre 1492) fols. 19 y 20; publicado por H. BEINART, Trujillo, doc. 80, págs. 247-248.

${ }^{102}$ F. CANTERA Burgos, «De epigrafía hebraicoespañola», pág. 111; F. CANTERa Burgos y J. M." Millas, Las inscripciones hebraicas de España (Madrid 1956) págs. 27-30, núm. 11. C. CARrete Parrondo, Fontes, doc. 76, pág. 41, dice que corresponde a la segunda mitad del siglo XII o primera del XIII.

${ }^{103}$ F. CANTERA BURgos, «De epigrafía hebraicoespañola», págs. 106-112.

104 J. Muñoz Domínguez, «La judería errante (X)», pág. 11, incluye un mapa urbano.
} 
das con las fuentes de archivo, pendientes de revisión por futuros trabajos de intervención arqueológica o investigación histórica.

\section{TIERRAS DE CULTIVO}

El fuero de Béjar garantiza la construcción de una casa y poseer un terreno de cultivo a los colonos judíos, cristianos y musulmanes que pueblen la villa de Béjar y sus aldeas. Por este motivo, cuando los judíos se exilian de Béjar, entre el patrimonio abandonado figuran casas y tierras de cultivos, principalmente viñedos. En julio de 1467, Çag Cohén posee una viña en propiedad en el término de la Asomada, camino de Navalmoral, limítrofe con el prado de Alfonso Ferrándes Nieto y la viña de García Sánchez de la Fuente ${ }^{105}$.

En mayo de 1492, rabí Yudá Cara vende a Diego Barbero una viña en el pago de Cabeza Roldán que linda con la viña de la Tetilla (¿Semuel de la Tetilla?) y la de Alfonso y con la viña de don Oro, en cuya transacción incluye un cesto de cuba con capacidad para recoger unos diez o doce cántaros de vino, una tina de madera, una tinaja para almacenar seis cántaros de vino y un azadón, a cambio de un asno valorado en treinta reales ${ }^{106}$.

Otro de los judíos exiliados de la aljama de Béjar, el zapatero don Semuel de la Tetilla, vende por $1.910 \mathrm{mrs}$ al cirujano maestre Luis dos viñas en el pago del Portón y en Prado Marcos por 1.910 mrs, cuya venta realiza el 23 de mayo de $1492{ }^{107}$.

No son éstas las únicas heredades que los judíos tienen en propiedad en el señorío de Béjar. También son dueños de otros heredamientos que traspasan a terceras personas o instituciones. En un cuestionario elaborado por los jueces comisarios de la casa de los

\footnotetext{
${ }^{105}$ AHN, Sección Nobleza. Osuna, leg. 216, núm. 6/4, C. Carrete Parrondo, Fontes, doc. 83.

${ }^{106}$ AHN, Sección Nobleza. Osuna, leg. 218, núm. 3/5, C. CArrete Parrondo, Fontes, doc. 86.

${ }^{107}$ AHN, Sección Nobleza. Osuna, leg. 218, núm. 3/6, C. Carrete Parrondo, Fontes, doc. 87.
} 
Zúñiga, en enero de 1495, preguntan al vecindario por el paradero de las propiedades privadas y comunales abandonadas por los judíos en el señorío de Béjar en 1492. En la relación figuran ${ }^{108}$-lo que no quiere decir que lo tuviesen en propiedad- las casas de las cofradías, hospitales, talleres textiles, linares (indispensables para la fabricación del textil), huertas de cultivo, castañares (cuyo fruto, la castaña, es la base de la alimentación rural hasta la importación americana de la patata), casas «troxes», o granero comunal, utilizado para guardar el trigo y otros productos campestres, tenerías para curtir las pieles edificadas en la cuenca de los ríos, palomares, etc.

¿Los judíos del señorío de Béjar cultivan con sus propias manos las heredades y tierras de labranza? Sólo podemos responder que poseen parcelas agrícolas, huertos, castaños y viñedos que, por su escaso rendimiento productivo, consideramos destinado al consumo familiar. No faltan herramientas agrícolas en las casas judiegas: un cesto de cuba para recoger vino, una tina de madera, una tinaja, un azadón.

\section{DEMOGRAFÍA JUdía EN EL SEÑORÍO DE BÉJAR, SIGLOS XIV-XV}

Concluimos el trabajo con un breve apunte sobre la demografía judía en el solar bejarano de los Zúñiga. A. Martín Lázaro ha lanzado una hipótesis de trabajo partiendo del dato de la contribución fiscal del «servicio y medio servicio» que pagan los judíos de Béjar y Hervás a la corona de Castilla en 1474. En opinión del autor ${ }^{109}$,

en el mencionado servicio cabía a cada vecino o cabeza de familia cincuenta maravedís, de donde tenemos un total de 140 judíos entre Béjar y Hervás. Conceptuando la mitad a Béjar tenemos 70 [familias de]

${ }^{108}$ AHN, Sección Nobleza. Osuna, leg. 218, núm. 4/2.

109 A. Martín Lazaro, «Geografía histórica de Béjar», $B M 8$ (1 junio 1924) págs. 6-7, cuyos datos recoge de T. González, Censo de población de las provincias y partidos de la Corona de Castilla en el siglo XVI (Madrid 1829) págs. 112-117. 
judíos en esta villa, que a cinco personas por cada vecino dan 350 habitantes de aquella raza.

El planteamiento demográfico de A. Martín Lázaro adolece de base histórica por varias razones. Primeramente, en Hervás hay menos de cuarenta y cinco cabezas de familias ${ }^{110}$, por lo que la distribución de setenta familias en cada localidad carece de fundamento. También hay comunidades judías o vecinos en Candelario ${ }^{111}$, La Calzada ${ }^{112}$, Gilbuena ${ }^{113}$ y otros lugares ${ }^{114}$, de manera que las exacciones fiscales deben distribuirse entre todas las familias pecheras judías que tienen vecindad en el señorío de Béjar.

En tercer lugar, los niveles demográficos judíos de la villa de Béjar superan a la comunidad de Hervás y al resto de las localidades de la tierra. ¿Cuántas familias judías habitan en Béjar? No estamos en condiciones de apuntar cifras concretas. Pero sí podemos despejar algunas incógnitas, como por ejemplo que la judería bejarana y los espacios geográficos de la Alcaicería y calle Mayor son notablemente superiores al de Hervás, que ni siquiera dispone de judería, según los documentos ${ }^{115}$. El archivero fray Liciniano Sáez hace mención a cuarenta casas que pertenecieron a los judíos de la villa embargadas por la corona y donadas al duque de Béjar ${ }^{116}$ :

\footnotetext{
${ }^{110}$ AHN, Sección Nobleza. Osuna, leg. 267, núm. 32; publicado en mi trabajo Los judios de Hervás (Hervás 1997; 3ª ed. 2000) págs. 8-9.

111 Véase mi trabajo "Noticias sobre los judíos de Candelario (Salamanca)», Sefarad 57 (1997) págs. 251-270, recogido en Los judios de Candelario (Hervás 1998).

112 AGS, RGS, (15 mayo 1494), fol. 209, C. CARrete Parrondo, Fontes, doc. 90.

${ }^{113}$ Un judío tiene una casa en propiedad, AHN, Sección Nobleza. Osuna, leg. 266, núm. 74, recogido por C. CARrete Parrondo, Fontes, doc. 89.

${ }^{114}$ Los jueces comisarios de la casa de Béjar solicitan información a los vasallos de la tierra sobre las propiedades que tenían los judíos en la «villa de Béjar e de los logares de Hervás e Candelario e Beçedas e Gilbuena e Solana e Santibáñez e Sorihuela e La Cabeça e Fuentes e todos logares de la tierra», AHN, Sección Nobleza. Osuna, leg. 218, núm. 3/1 y C. Carrete Parrondo, Fontes, doc. 93; y en «Candelario, Beçedas, Gilbuena, Solana, Santibáñez», leg, 266, núm 74, C. Carrete Parrondo, Fontes, doc. 94.

${ }^{115}$ Véase en mi trabajo Los judios de Hervás (Hervás 1997; 3a ed. 2000).

${ }^{116}$ Información y comentario de fray L. Sáez en AHN, Sección Nobleza, Osuna, leg. 216, núm. 6/12.
} 
40 casas en Béjar que fueron de los judíos, a quienes se confiscaron en su expulsión, y de que los señores RRCC. hicieron gracia a los duques, con los demás bienes que esta mala canalla tenía y posehía en sus estados, por remuneración de sus grandes servicios en lanzarlos, y a los moriscos de Granada y Castilla, a mucha costa de armas y dineros, y asimismo otras heredades y bienes en otros estados.

Estas propiedades proceden de los bienes que abandonan los judíos antes de su partida en $1492^{117}$, de los bienes que venden a bajo precio y recupera la casa de Béjar en $1495^{118}$, y de los bienes incautados por la Inquisición a los conversos judaizantes del señorío de Béjar en 1514-15 ${ }^{119}$.

En el recuento demográfico de 1528,1530 y $1534{ }^{120}$, que no incluye al clero secular y regular, pero sí a los conversos, la villa de Béjar registra 558 vecinos pecheros, Candelario 266, Becedas, Palacio y Berrocal 264, Gilbuena 203, Hervás 178, Solana, La Zarza, Tremedal y Macelinos 147, Santibáñez 126, Sorihuela 116, El Puerto de Béjar 112, Baños de Béjar 111, La Garganta 109, etc. Según éste censo, Hervás ocupa el quinto lugar más poblado del señorío, después de Béjar, Candelario, Becedas y Gilbuena. En 1534 , la proporción del vecindario cristiano y converso de la villa de Béjar con relación a Hervás es de 3,13 habitantes por 1 . ¿Podría servirnos la cifra de 3 a 1 como posible punto de referencia para establecer una correlación demográfica entre los vecinos judíos de la aljama de Béjar y la comunidad de Hervás?

\footnotetext{
${ }^{117}$ Sólo hay datos de la casa de rabí Yudá de Coca y de la sinagoga, en AHN, Sección Nobleza. Osuna, leg. 266, núm. 74, y C. CARrete PARrondo, Fontes, doc. 89.

${ }^{118} \mathrm{Se}$ conservan los contratos de cuatro casas recuperadas por la casa de Béjar, AHN, Sección Nobleza. Osuna, leg. 218, núms. 3/5, 3/6, 3/7 y 3/8

${ }^{119}$ En mi trabajo «La Inquisición en el señorío de Béjar», págs. 661-698.

${ }^{120}$ T. GonZÁleZ, Censo de población, págs. 52, 57 y 100.
} 


\section{RESUMEN}

La comunidad judía se estableció en Béjar durante la Reconquista cristiana de Alfonso VIII, quien desarrolló una legislación jurídica que protegía la vida de los judíos. La comunidad estableció la judería y la sinagoga en el barrio de San Gil, aunque los judíos también vivieron en la Alcaicería y en la calle Mayor. Proclamado el edicto de expulsión, la sinagoga fue saqueada y destruida.

PALABRAS ClAVE: Béjar, demografía, fueros, barrio judío, sinagoga.

\section{SUMMARY}

The Jewish community of Bejar established during the Christian Reconquist by Alfonso VIII, who conceded legal legislation to protect the life of the Jews. The Jewish quarter and the synagogue were established in the Saint Gil district, but some Jews lived in the Alcaicería and the Calle Mayor as well. When the edict of expulsion was proclaimed, the synagogue was sacked and destroyed.

KEYwORDS: Bejar, demography, laws, Jewish quarter, synagogue. 